\author{
MASSIMILIANO CENTORAME $(*)$ - ANDREA LANCIA $(* *)$ - ERMANNO MORI $(*)$ \\ DARIO D'EUSTACCHIO $(*)$ - ALBERTO FANFANI $(*)$
}

\title{
COULD LINEPITHEMA HUMILE (HYMENOPTERA FORMICIDAE) INFLUENCE ANT COMMUNITY COMPOSITION? A PRELIMINARY STUDY IN A NATURAL AREA IN ITALY $\left({ }^{1}\right)$
}

\author{
(*) Dipartimento di Biologia e Biotecnologie 'Charles Darwin', Università degli Studi di Roma 'La Sapienza', Viale \\ dell'Università 32, 00185, Roma, Italy \\ (**) Dipartimento di Medicina Clinica, Sanità Pubblica, Scienze della Vita e dell'Ambiente, Università degli Studi dell'Aquila \\ Piazzale Salvatore Tommasi 1, 67100 Coppito (L'Aquila), Italy \\ Corresponding author: Massimiliano Centorame; e-mail: massimiliano.centorame@uniroma1.it
}

Centorame M., Lancia A., Mori E., D'Eustacchio D., Fanfani A. - Could Linepithema humile (Hymenoptera Formicidae) influence ant community composition? A preliminary study in a natural area in Italy.

The Argentine ant, Linepithema humile, is an invasive species widespread in the Mediterranean climatic regions of the world, which is well demonstrated to have a negative impact on native ants and on the community structure. At the beginning of the twentieth century its presence was recorded for the first time in Italy and currently is mainly found along the Tyrrhenian coast, where it locally shows a patchy distribution. In our study we investigated an environmentally homogenous transect including an invaded area and a control zone inside the Presidential Estate of Castelporziano, to evaluate possible impact of the Argentine ant on the native species and differences in ant community composition. For our purpose we used pitfall traps and an active field sampling along the transect, with six replicates from April to August 2015. The sampling indicated a significant reduction of the number of species in the invaded area, while the multivariate analysis and the percentage of species in both the zones showed a different ant community composition between invaded and uninvaded areas. These findings were also supported by very different values of the diversity indices calculated for each zone and the lower number of functional groups found in the invaded area. According to literature, we conclude that L. humile could be the species mainly responsible for this arrangement. Future study using a higher spatial scale and covering a larger variety of habitats is certainly required.

KeY WoRDS: Argentine ant; invasive species; community composition; Castelporziano Estate.

\section{INTRODUCTION}

Over 200 ant species have established populations outside their native ranges. Among these, many have become highly destructive invaders, and five (the Argentine ant Linepithema humile, the big-headed ant Pheidole megacephala, the yellow crazy ant Anoplolepis gracilipes, the little fire ant Wasmannia auropunctata, and the red imported fire ant, Solenopsis invicta) are currently listed among the world's 100 worst invasive species (MCGLYNN, 1999; LOWE et al., 2000; SUAREZ et al., 2010).

In particular, the Argentine ant, Linepithema humile, is considered one of the most invasive species in the world, spreading primarily via human mediated transport (LowE et al., 2000; TSUTSUI \& SUAREZ, 2003). Native of South America, it occurs throughout the world, with at least 28 separate known introductions in areas with Mediterranean climate and with temperate and subtropical ones (SUAREZ et al., 2001). In the last decades, many studies have showed that L. humile has a negative impact on native ants and, indirectly, on seeds dispersion and vertebrate fauna (HUMAN \&

${ }^{1}$ This research was part of the $\mathrm{PhD}$ thesis of Dario D'Eustacchio who died $14^{\text {th }}$ October 2014 before finishing to elaborate and write the final results. This paper is dedicated to his memory.
GORDON, 1999; CARNEY et al., 2003; GOMEZ et al., 2003; CARPINTERO et al., 2005, 2007; SUAREZ et al., 2005; HANNA et al., 2015). The main feature that has favored the spread of the Argentine ant in the introduced range is the unicoloniality: a colonial structure originated from intraspecific aggression loss and the adoption of budding as a dispersion mechanism (Holway, 1998; Heller \& Gordon, 2006). On the contrary, in their native range, Argentine ant colonies have a different structure, known as multicoloniality, consisting of multiple nests occupying relatively small territories that are aggressively defended against other intraspecific colonies, although larger colonies can be found (Tsutsui \& SUAREZ, 2003).

In Europe, the Argentine ant forms two enormous supercolonies, one located in Catalonia and the other ranging over $6000 \mathrm{~km}$ from the Atlantic to the Mediterranean coasts, from Portugal to Italy (GIRAUD et al., 2002; JAQUIÉRY et al., 2005). In this area it has been demonstrated that $L$. humile displaces native ants (CARPINTERO et al., 2007) although some native species act as limiting factors. One of these is Tapinoma nigerrimum s.l. (sensu lato after SEIFERT et al. 2017), as demonstrated by studies conducted in Corsica and Italy (BLIGHT et al., 2010; D'EusTACCHIO et al., 2014).

Considering the high diversity of ant species in invaded areas, the spread of Argentine ants in Italy is an alarming phenomenon in terms of ant biodiversity loss. At the moment, L. humile is found along all the Tyrrhenian and 
Ionian coasts, including Sicily and Sardinia, and along the south Adriatic coast (personal observation). A preliminary study conducted in Italy by D'Eustacchio et al. (2014) demonstrated that the Argentine ant and T. nigerrimum s.l show a local abundant and patchy distribution with several frontline areas reflecting competitive exclusion.

Our research investigates one of these frontline areas, dividing the area where $L$. humile is present from the area where only native ants occur, with the aims: (1) evaluate the presence of significant differences in species richness and diversity between the two areas; (2) compare the community composition of the areas by using a functional group approach and cluster analysis methods.

\section{MATERIALS AND METHODS}

The site selected for our study is located inside the Presidential Estate of Castelporziano (Fig. I, 2): a natural reserve instituted in 1999 by the Italian government. The Estate is located in Central Italy along the Tyrrhenian coast $\left(41.71201^{\circ} \mathrm{N}, 12.39732^{\circ} \mathrm{E}\right)$, with extent of $61.47 \mathrm{~km}^{2}$ and consists of several representative habitats: a large pristine beach habitat, recent dunes colonized by pioneer species, ancient dunes with retrodunal wet areas, low and high mediterranean maquis with evergreen and aromatic species and finally lowlands characterized by oak-species (CAStracani et al., 2010; Spotti et al., 2010). Castelporaziano Estate is an important, well-known biodiversity area. To date, about 1000 plant species and 2900 vertebrate and invertebrate species have been identified (AA.VV., 2001, 2006). The family Formicidae is well represented with 55 species (about a fifth of the Italian myrmecofauna) known to be present before this study (FANFANI et al. 2006, CASTRACANI et al., 2010) including the invasive species $L$. humile.

For our investigation we placed a transect in a site located along a dirt track between an artificial canal and oak forest $\left(41.69077^{\circ} \mathrm{N}, 12.37275^{\circ} \mathrm{E}\right)$ (Fig. I, 1). We conducted six pitfall trap sessions from April to August 2015. The length of the transect was $80 \mathrm{~m}$ consisting of three different zones. The first, including the pitfall traps from P1 to P4, represented the side of transect with the presence of $L$. humile. We named this zone LHU. The second, named CON, included the pitfall traps from P6 to P9 and represented the control zone as the Argentine ant was absent. The third zone represented the frontline between the others two zones and was named FRO. This zone including P5 was placed in the midline of the transect between the last nest of the Argentine ant we could trace and the first nest of the other ant species discovered. For our study, frontline was recorded in April 2015. This was necessary because along this transect the frontline position changed over the years (personal observation).

We used pitfall traps to estimate the abundance and species composition of ground surface-active ants along the transect (Bestelmeyer et al., 2000). Pitfall traps were placed every $10 \mathrm{~m}$ and left open for $48 \mathrm{~h}$. Propylene glycol was chosen as the killing agent mainly because it is slow to evaporate, non-attractive, non-repellent and a good conservation agent (BESTELMEYER et al., 2000). One of the greatest advantages of pitfall traps is that they involve multi-day continuous passive sampling, although they can miss wary species (MENKE \& VACTHER, 2015). For this reason we conducted a hand sampling for 2 hours within 3 meters on left and right in respect of the line of transect. All species were recorded with the respective position in the transect. Uncertain specimen were collected for morphological identification, which was carried out for the most part by the authors. Tapinoma sp. collected along the transect was identified based on the molecular data provided by the first author. Additional problematic identifications were resolved by Dr. Fabrizio Rigato of the Museum of Natural History of Milan.

Species accumulation curves were constructed to verify the adequacy of sampling effort using the $\mathrm{R}$ package "Vegan", version 2.3-3 (OKSANEN et al., 2016).

Statistical analysis was focused on the comparison between pitfall traps belonging to LHU and CON zones in terms of species richness $(\mathrm{S})$ and total abundance $(\mathrm{N})$ resulting from each of the 6 sampling sessions. The nonparametric Mann-Whitney U test was used to compare the number of species and specimen abundance and evaluate the significance of the difference between the two sides of transect. Furthermore, for each zone, the same variables were used to calculate the following diversity indices: Margalef's (d), Pielou's (J'), Shannon (H') and GiniSimpson (1-Lambda') (RETANA \& CERDÁ, 2000). In a second step a multivariate approach was used to evaluate possible changes in species composition along the transect. For this purpose, cluster analysis was used to observe how

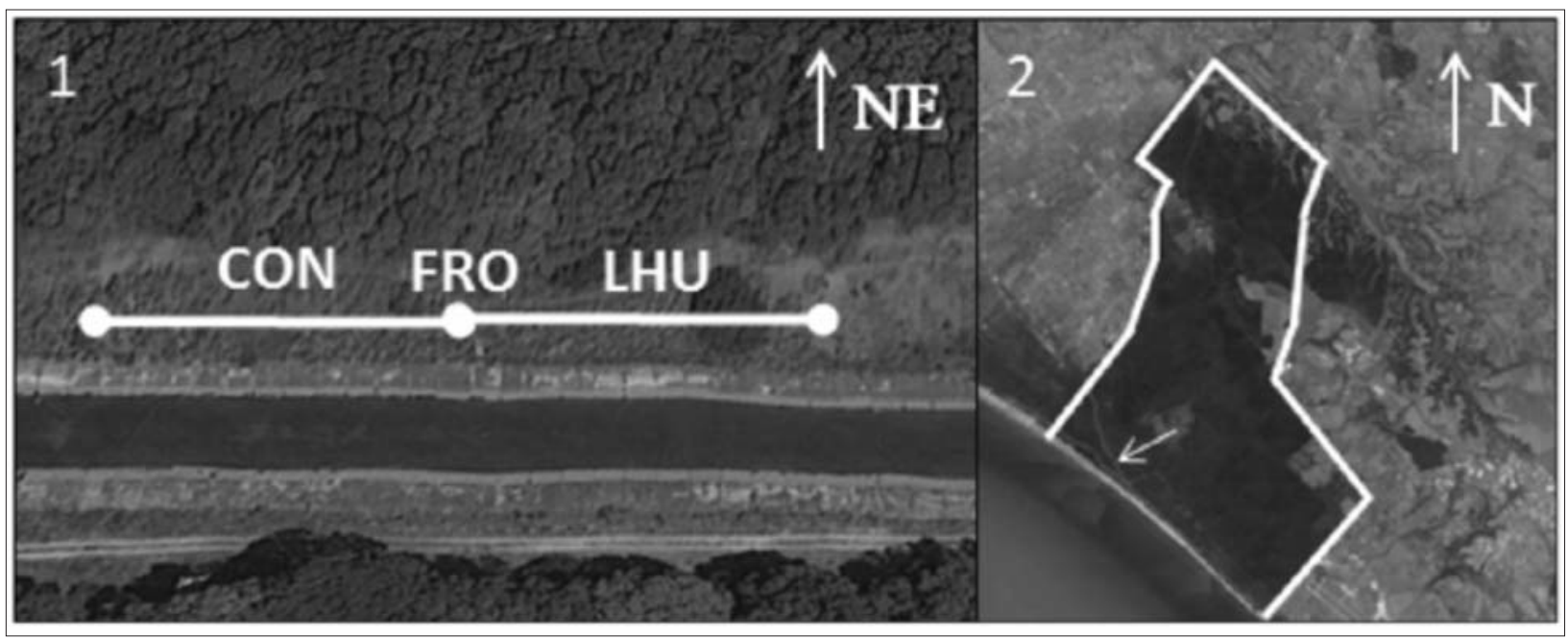

Fig. I - 1. Transect map with the three sampling zones: control (CON), frontline (FRO) and invaded (LHU); 2. Map of Castelporziano: the arrow points out the sampling area. 
pitfall traps grouped considering species absence/presence of each pitfall trap. For this analysis, the results of each pitfall of every session were summed. The clustering was based on dissimilarity values from the Bray-Curtis index (BRAY \& CURTIS, 1957). This approach allowed us to understand if the pitfall traps were grouped one with another according to the relevant zone and to a different ant composition. We also used a Functional Group Approach to explain differences in ant community structure (CASTRACANI et al., 2010) between LHU and CON. For this, we calculated the percentage of the presence of each species in both zones to verify the exclusivity of the species. Finally, we associated each species with a functional group according to Brown (2000) to evaluate structural complexity differences between LHU and $\mathrm{CON}$ communities.

All statistical analyses were performed using PAST 2.17c (HAMMER et al., 2001).

\section{RESULTS}

Pitfall traps and hand sampling indicated the presence of 21 ant species belonging to 10 genera (Table 1) and a total of 6688 individuals sampled with pitfall traps. The species accumulation curves of TOT and LHU (Fig. II) tended to plateau indicating an adequate sampling effort. Considering only CON curve, we expected more species than those collected.

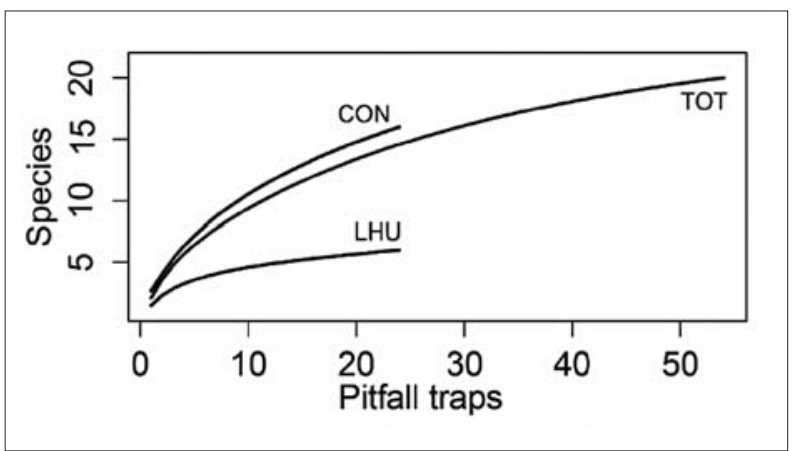

Fig. II - Species accumulation curves. Each line represent: the total sampling (TOT), the control zone alone $(\mathrm{CON})$ and the in invaded zone (LHU)

The number of species and the relative abundances did not result uniform in the different traps. Considering all sessions, P5, P6 and P8 represented the pitfall traps with the largest number of species while T. magnum and L. humile were the species that counted the largest number of specimens with, respectively, 6186 and 312 sampled specimens. Among the not dominant species, only $M$. minor and $S$. fugax were recorded with a number of individuals higher than 26, with, respectively, 89 and 58 sampled specimens. Species richness (LHU, mean \pm ES: $1.5 \pm 0.18$; CON, mean \pm ES: $2.58 \pm 0.31$ ) and specimens abundances (LHU, mean \pm ES: $11.83 \pm 2.79 ; \quad C O N$, mean \pm ES:

Table 1 - Percentages of workers found in control zone and in the invaded zone for each species, sampled using pitfall traps. Pheidole pallidula is the only species collected by active field sampling.

\begin{tabular}{|c|c|c|c|}
\hline SPECIES & LHU / CON* & SPECIES & LHU / CON \\
\hline $\begin{array}{c}\text { Aphaenogaster subterranea } \\
\text { (Latreille, 1798) }\end{array}$ & $100 \% / 0 \%$ & Temnothorax sp. & $0 \% / 100 \%$ \\
\hline $\begin{array}{l}\text { Camponotus aethiops } \\
\text { (Latreille, 1798) }\end{array}$ & $0 \% / 100 \%$ & $\begin{array}{l}\text { Temnothorax affinis } \\
\text { (Mayr, 1855) }\end{array}$ & $0 \% / 100 \%$ \\
\hline $\begin{array}{l}\text { Camponotus lateralis } \\
\text { (Olivier, 1792) }\end{array}$ & $0 \% / 100 \%$ & $\begin{array}{c}\text { Temnothorax cf. alienus } \\
\text { Schulz, Heinze \& Pusch, } 2007\end{array}$ & $0 \% / 100 \%$ \\
\hline $\begin{array}{l}\text { Colobopsis truncata } \\
\quad \text { (Spinola, 1808) }\end{array}$ & $0 \% / 100 \%$ & $\begin{array}{l}\text { Temnothorax angustulus } \\
\quad \text { (Nylander, 1856) }\end{array}$ & $0 \% / 100 \%$ \\
\hline $\begin{array}{l}\text { Formica cunicularia } \\
\quad \text { Latreille, } 1798\end{array}$ & $0 \% / 100 \%$ & $\begin{array}{l}\text { Temnothorax aveli } \\
\text { (Bondroit, 1918) }\end{array}$ & $0 \% / 100 \%$ \\
\hline $\begin{array}{l}\text { Linepithema humile } \\
\text { (Mayr, 1868) }\end{array}$ & $99 \% / 1 \%$ & $\begin{array}{l}\text { Tetramorium caespitum } \\
\quad \text { (Linnaeus, 1758) }\end{array}$ & $100 \% / 0 \%$ \\
\hline $\begin{array}{l}\text { Messor minor } \\
\text { (André, 1883) }\end{array}$ & $0 \% / 100 \%$ & $\begin{array}{c}\text { Tetramorium diomedeum } \\
\text { Emery, } 1908\end{array}$ & $0 \% / 100 \%$ \\
\hline $\begin{array}{l}\text { Messor wasmanni } \\
\text { Krausse, } 1910\end{array}$ & $0 \% / 100 \%$ & $\begin{array}{c}\text { Temnothorax flavicornis } \\
\text { (Emery, 1870) }\end{array}$ & $100 \% / 0 \%$ \\
\hline $\begin{array}{l}\text { Pheidole pallidula } \\
\text { (Nylander, 1849) }\end{array}$ & $0 \% / 100 \%$ & $\begin{array}{l}\text { Temnothorax recedens } \\
\text { (Nylander, 1856) }\end{array}$ & $0 \% / 100 \%$ \\
\hline $\begin{array}{l}\text { Solenopsis fugax } \\
\text { (Latreille, 1798) }\end{array}$ & $52 \% / 48 \%$ & $\begin{array}{c}\text { Tetramorium semilaeve } \\
\text { André, } 1883\end{array}$ & $100 \% / 0 \%$ \\
\hline $\begin{array}{c}\text { Tapinoma magnum } \\
\text { Mayr, } 1861\end{array}$ & $0 \% / 100 \%$ & & \\
\hline \multicolumn{4}{|c|}{$\begin{array}{l}\text { *we reported the equation used to calculate the percentages of each species } \\
\%=\frac{\text { zon }}{(\text { tot }- \text { fro })} \times 100\end{array}$} \\
\hline \multicolumn{4}{|c|}{$\begin{array}{l}\text { zon }=\text { number of specimens of } i \text {-species collected in } \mathrm{LHU} \text { or CON in all pitfall sessions } \\
\text { fro }=\text { number of specimens of } i \text {-species collected in P5 in all pitfall sessions } \\
\text { tot }=\text { number of specimens of } i \text {-species collected in whole transect in all pitfall sessions }\end{array}$} \\
\hline
\end{tabular}


264.25 \pm 40.42 ) showed significant difference between LHU and CON (S: $U=154.5, p<0.01 ; \mathrm{N}: \mathrm{U}=15, \mathrm{p}<0.001$ ). Accordingly, also the index values showed high differences between the zones (Table 2).

Table 2 - List of diversity indices calculated for the invaded and uninvaded zones. Species richness (S), total abundance $(\mathrm{N})$, Margalef's (d), Pielou's (J'), Shannon (H') and Gini-Simpson (1Lambda'). The values represent the mean of the diversity indices calculated for each zones in the different sessions.

\begin{tabular}{ccccccc}
\hline \hline $\mathrm{s}$ & $\mathbf{S}_{\text {tot. }}$ & $\mathbf{N}_{\text {tot. }}$ & $\mathbf{d}$ & $\mathbf{J}$ & H' & 1-Lambda' \\
\hline CON & 16 & 6344 & 1.71 & 0.06 & 0.17 & 0.05 \\
LHU & 6 & 287 & 0.88 & 0.44 & 0.80 & 0.37 \\
\hline
\end{tabular}

Since a significant difference has been demonstrated, cluster analysis (Fig. III) revealed two main groups corresponding to CON and LHU. Frontline pitfall trap (P5) grouped with $\mathrm{CON}$ cluster. In fact, the percentages of the presence demonstrated that the species were exclusive of a zone rather that another. The exceptions were L. humile with $1 \%$ of the presence in the control zone and S. fugax recording about $50 \%$ between two zones (Table 1).

Finally, Table 2 shows how the change in ant composition reflects also the complexity of each zone in terms of functional groups. The species present in the Argentine ant side were associated with four functional groups whilst in the control side three more functional groups were present (Table 3).

\section{DISCUSSION}

In our research, we sampled 21 ant species that correspond to about $50 \%$ of the ant species identified in the entire Presidential Estate of Castelporziano. Moreover, we identified more species comparing D'EustaCCHIO et al. (2014) that conducted an extensive sampling inside the same Estate. Species accumulation curves indicated a good

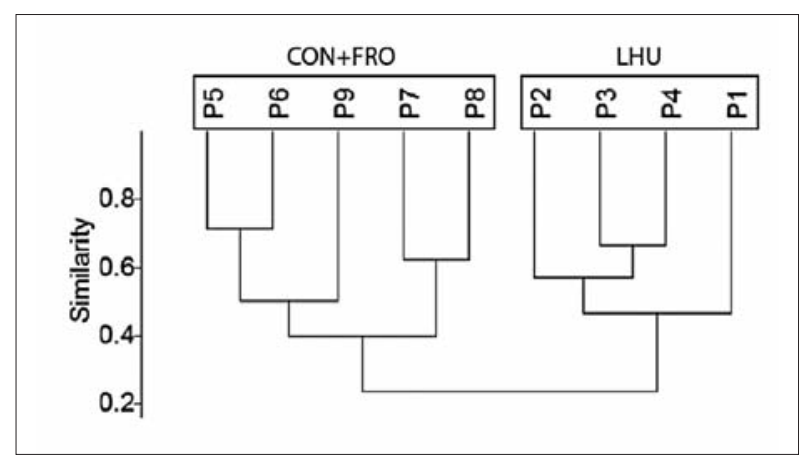

Fig. III - Dendrogram constructed with the method of cluster analysis based on dissimilarity Bray-Curtis values. The pitfall traps P5-P9 (highlighted with a rectangle as $\mathrm{CON}+\mathrm{FRO}$ ) and P1-P4 (highlighted with a rectangle as LHU) form, respectively, the two main clusters. The values of similarity (reverse of dissimilarity Bray-Curtis values) are bound between 0 and, where 1 means the two sites have the same composition (that is they share all the species), and 0 means the two sites do not share any species.

sampling effort for our aims. In fact, although the number of species in the uninvaded area seems to be underestimated, recording more species in this zone can only strengthen the following proposed hypothesis. Although, the sampling effort is not extensive enough to verify the impact of the Argentine ant on a large scale, our data resulted suitable for a preliminary research aimed to promote a hypothesis on the impact of the Argentine ant on native species.

Comparing the two zones, in the invaded area were found only 6 species and 284 individuals against 16 species and 6342 of the control area. Similarly, diversity indices values calculated for the invaded and control zones were very different, but with the greater values associated with the zone poorest of species (except Margalef's index). In fact, the other indices show lower values in the control area caused by the high numeric abundance of the specimens of $T$. magnum. In the invaded area, L. humile, despite being the most abundant species in its own territory, was present with a much lower amount of individuals than T. magnum.

Table 3 - List of species collected in each of the two zones (CON and LHU) and the corresponding functional groups.

\begin{tabular}{|c|c|c|}
\hline Dominant Dolichoderinae (DD) & Linepithema humile & Tapinoma magnum \\
\hline Opportunist (O) & $\begin{array}{c}\text { Tetramorium caespitum } \\
\text { Tetramorium semilaeve } \\
\text { Aphaenogaster subterranea }\end{array}$ & $\begin{array}{l}\text { Formica cunicularia } \\
\text { Tetramorium diomedeum }\end{array}$ \\
\hline Cold Climate Specialist (CCS) & Temnothorax flavicornis & $\begin{array}{l}\text { Temnothorax angustulus } \\
\text { Temnothorax aveli } \\
\text { Temnothorax sp. } \\
\text { Temnothorax cf. alienus } \\
\text { Temnothorax recedens } \\
\text { Temnothorax affinis }\end{array}$ \\
\hline Cryptic (C) & Solenopsis fugax & Solenopsis fugax \\
\hline Subordinate Camponotini (SC) & & $\begin{array}{l}\text { Camponoyus aethiops } \\
\text { Camponotus lateralis } \\
\text { Colobopsis truncata }\end{array}$ \\
\hline Hot Climate Specialist (HCS) & & $\begin{array}{c}\text { Messor minor } \\
\text { Messor wasmanni }\end{array}$ \\
\hline Generalized Myrmicinae (GM) & & Pheidole pallidula \\
\hline
\end{tabular}


On the other hand, Margalef's index shows a higher value for the control area, because its formula gives more weight to the number of present species, that was higher in the control area. In other words, the community in the control area is more rich in species and individuals but uneven, while the invaded area is less rich but more even.

Although in the invaded area were collected less species than in control one, we cannot assume that the Argentine ant is responsible of the reduction of the number of species since each species recorded in the invaded zone is exclusive of that area. Nevertheless, several studies demonstrated the higher exploitation and interference ability of Argentine ant compared to native ant species, securing a majority of available food resources (HUMAN \& GORDON, 1996; Holway, 1999; Human \& Gordon, 1999; Rowles \& O'DowD, 2007), the ability to displace ant native species in invaded sites (ERIKSON, 1971; WARD, 1987; ROURAPASCuAl et al., 2009; Rowles \& O'DOWD, 2009) and to change, significantly, ant composition of a site after the invasion (ROURA-PASCUAL et al., 2009; ROWLES \& O'DOWD, 2009). Accordingly, comparing our results with literature data, we can hypothesize that the main cause of the observed community structure variation between the sides of transect is the Argentine ant.

Furthermore, we can observe in the invaded area the absence of species that foraged above ground (epigeic). This result is supported by WARD (1987) and ROWLES \& O'Dowd (2009) that observed the strong effect of $L$. humile on epigeic ants, the most susceptible to displacement. Instead, small hypogeic ants were more resistant to the invasion probably because they were less likely to encounter and interact with the Argentine ant. Among these species, Rowles \& O'DOwD (2009) cited Solenopsis spp. that we collected in both the invaded and not invaded zones, highlighting that the Argentine ant does not affect their distribution. Investigating the biology of S. fugax, we can better explain the reason for no problematic presence of this taxon in an invaded zone. In fact, this species tended to live inside the nest of larger species or to enter into their chambers stealthily to steal food or prey on brood, the typical behaviour of lestobiotic ants (ANTONOVA, 2004). For this reason, this species could benefit from the presence of both T. magnum and L. humile.

The decline of species richness can favor some species that become free from competition. This process leads to an homogenization of the community structure, as also revealed by ROURA-PASCUAL et al. (2009). In our study, the Functional Group Approach recognized this trend. It is clear that the control area had a far more complex and rich ant community composition, hosting 7 different functional groups, most of which represented by a respectable number of species, while in the invaded area 4 functional groups were present, with only the opportunists being represented by more than one species. All 4 groups found in the invaded area were present in the control zone too. This means that, differently to what occurs in the species composition, there is no change in the type of functional groups found, only a reduction of their number between the two areas. The groups absent in the invaded area were Subordinate Camponotini, Hot Climate Specialists and Generalized Myrmicinae. Regarding Hot Climate Specialist, M. minor resulted to be very abundant in the control area. The coexistence of this species with a numerically dominant one like T. magnum, without aggressive interactions, can be explained by the low niche overlap between these species. In fact, $M$. minor is a granivorous species rather than a generalist like T. magnum. L. humile does not feeds on seeds, nevertheless granivorous species are totally absent in the invaded area. This can be due to the unconditioned aggressive behaviour of the Argentine ant and its territoriality, which leads to the loss of a functional group that could be easily sustained by the environment.

In conclusion, we think that such a radical change in community structure in a homogeneous environment is almost certainly a consequence of the presence of one or more different species in the two areas capable of shaping the communities by sheer competition. The more likely candidate is the Argentine ant for the reasons previously cited. Future studies of this type, made on a higher spatial scale, covering a larger variety of habitats are certainly required to shed more light on this subject, and obtain more decisive results on the causes and consequences of this kind of ecological arrangement.

\section{ACKNOWLEDGEMENTS}

We are grateful to the Segretariato Generale della Presidenza della Repubblica, to the Director of the Castelporziano Estate for the hospitality in the guest-house and to the Osservatorio Centro Multidisciplinare degli Ecosistemi Costieri Mediterranei. We wish to thank Patricia de Angelis for reviewing the text in English, Fabrizio Rigato of the Museum of Natural History of Milan for identification of ant species and Prof. Maurizio Biondi of the University of L'Aquila. All research conducted complied with the current legislation in Italy.

\section{REFERENCES}

AA.VV. (Eds), 2001 - Il sistema ambientale della Tenuta Presidenziale di Castelporziano. Ricerche sulla complessità di un ecosistema forestale costiero mediterraneo. - Accademia Nazionale delle Scienze detta dei XL, Scritti e Documenti, 26, 2 volumi, 866 pp.

AA.VV. (Eds), 2006 - Il sistema ambientale della Tenuta Presidenziale di Castelporziano. Ricerche sulla complessità di un ecosistema forestale costiero mediterraneo. - Accademia Nazionale delle Scienze detta dei XL, Scritti e Documenti, 37, 3 volumi, 1853 pp.

Antonova V., 2004 - Compound nests and mixed colonies of ant species (Hymenoptera, Formicidae) in SofiaBulgaria. In: Ecology of the City of Sofia. Species and Communities in Urban Environment, Penev L., Niemala J., Kotze D. J., Chipev N. Eds., Pensoft Publishers, SofiaMoscow, pp. 423-428.

Bestelmeyer B.T., Agosti D., Alonso L.E., Brandão C.R.F., Brown W.L., Delabie J.H.C., Silvestre R., 2000 - Field techniques for the study of Ground-Dwelling Ants. In: Ants: standard methods for measuring and monitoring biodiversity, Agosti D., Mayer K.D., Alonso L.E., Schultz T.R. Eds., Smithsonian Institution Press, Washington DC, pp 122-269.

Blight O., Provost E., Renucci M., Tirard A., Orgeas J., 2010 - A native ant armed to limit the spread of the Argentine ant. - Biological Invasions, 12(11): 3785-3793.

BraY J. R., CURTIS J. T., 1957 - An ordination of upland forest communities of southern Wisconsin. - Ecological Monographs, 27: 325-349.

BROWN W.L.J., 2000 - Diversity of ants. In: Ants: standard methods for measuring and monitoring biodiversity, Agosti D, Majer J, Alonso L, Schultz T Eds., Smithsonian Institution Press, Washington DC, pp 45-88. 
Carney S.E., Byerley M.B., Holway D.A., 2003 Invasive Argentine ants (Linepithema humile) do not replace native ants as seed dispersers of Dendromecon rigida (Papaveraceae) in California, USA. Oecologia, 135(4): 576-582.

Carpintero S., Reyes-López J., De Reyna L.A., 2005 Impact of Argentine ants (Linepithema humile) on an arboreal ant community in Donana National Park, Spain. - Biodiversity \& Conservation, 14(1): 151-163.

Carpintero S., Retana J., Cerdá X., Reyes-López J., \& DE REYNA L.A., 2007 - Exploitative strategies of the invasive Argentine ant (Linepithema humile) and native ant species in a southern Spanish pine forest. Environmental Entomology, 36(5): 1100-1111.

Castracani C., Grasso D.A., Fanfani A. \& Mori A., 2010 - The ant fauna of Castelporziano Presidential Reserve (Rome, Italy) as a model for the analysis of ant community structure in relation to environmental variation in Mediterranean ecosystems. - Journal of Insect Conservation, 14(6): 585-594.

D’Eustacchio D., Fanfani A., Grasso D.A., 2014 Tapinoma nigerrimum as safeguard for Italian myrmecofauna against Argentine ant. - 17th Congress of the International Union for the Study of Social Insects (IUSSI), Cairns, Australia, 13-18 July 2014.

ERICKSON J.M., 1971 - The displacement of native ant species by the introduced Argentine ant, Iridomyrmex humilis Mayr. - Psyche, 78(4): 257-266.

Fanfani A., Nardi G., Folletto A., Tinelli A., $2006-$ Elenco (checklist) degli organismi segnalati nella Tenuta Presidenziale di Castelporziano. Il Sistema Ambientale della Tenuta Presidenziale di Castelporziano. Accademia Nazionale delle Scienze detta dei XL, II serie, Vol. III "Scritti e Documenti” XXXVII, pp. 1607-1842.

Giraud T., Pedersen J. S., Keller L., 2002 - Evolution of supercolonies: the Argentine ants of southern Europe. Proceedings of the National Academy of Sciences, 99(9): 6075-6079.

Gómez C., Pons P., BAs J.M., 2003 - Effects of the Argentine ant Linepithema humile on seed dispersal and seedling emergence of Rhamnus alaternus. -Ecography, 26(4): 532-538.

Hanna C., Naughton I., Boser C., Alarcón R., Hung K.L.J., Holway D. 2015 - Floral visitation by the Argentine ant reduces bee visitation and plant seed set. Ecology, 96(1): 22 - 230.

HAMMER R., HARPER D.A.T., RYAN P. D., 2001 - PAST: Paleontological Statistics Software Package for Education and Data Analysis. - Palaeontologia Electronica, 4(1): 1-9.

Heller N.E., Gordon D.M., 2006 - Seasonal spatial dynamics and causes of nest movement in colonies of the invasive Argentine ant (Linepithema humile). Ecological Entomology, 31(5): 499-510.

HoLwAY D.A., 1998 - Effect of Argentine ant invasions on ground-dwelling arthropods in northern California riparian woodlands. - Oecologia, 116(1-2): 252-258.

HolwaY D.A., 1999 - Competitive mechanisms underlying the displacement of native ants by the invasive Argentine ant. - Ecology, 80(1): 238-251.

HuMAN K.G. \& GoRDON D.M., 1996 - Exploitation and interference competition between the invasive Argentine ant, Linepithema humile, and native ant species. Oecologia, 105(3): 405-412.

Human K.G., Gordon D.M., 1999 - Behavioral interactions of the invasive Argentine ant with native ant species. - Insectes Sociaux, 46(2): 159-163.
JaQuiery J., Vogel V., Keller L., 2005 - Multilevel genetic analyses of two European supercolonies of the Argentine ant, Linepithema humile. - Molecular Ecology, 14(2): 589-598.

Lowe S., Browne M., Boudjelas S., De Poorter M., 2000 - 100 of the world's worst invasive alien species: a selection from the global invasive species database. Auckland: Invasive Species Specialist Group, 1-12.

MenKe S.B, VACHTER N., 2015 - A comparison of the effectiveness of pitfall traps and Winkler litter samples for characterization of terrestrial ant (Formicidae) communities in temperate savannas. - The Great Lakes Entomologist, 47 (3-4): 149-165.

MCGLYNN T.P., 1999 - The worldwide transfer of ants: geographical distribution and ecological invasions.Journal of Biogeography, 26(3): 535-548.

Oksanen J., Blanchet F.G., Kindt R., Legendre P., Minchin P.R., O’hara R. B., Gavin L. Simpson, Solymos P., Stevens M.H.H., WAGNer H., 2016 - Vegan: Community Ecology Package. R package version 2.3-3 (http://CRAN.R-project.org/package=vegan)

Retana J., Cerdá X., 2000 - Patterns of diversity and composition of Mediterranean ground ant communities tracking spatial and temporal variability in the thermal environment. Oecologia, 123(3): 43-444.

Rowles A.D. \& O'DowD D.J., 2007 - Interference competition by Argentine ants displaces native ants: implications for biotic resistance to invasion. - Biological Invasions, 9(1): 73-85.

Rowles A.D. \& O'Dowd D.J., 2009 - Impacts of the invasive Argentine ant on native ants and other invertebrates in coastal scrub in south eastern Australia. - Austral Ecology, 34(3): 239-248.

Roura-Pascual N., Brotons L., Peterson A.T., Thuiller W., 2009 - Consensual predictions of potential distributional areas for invasive species: a case study of Argentine ants in the Iberian Peninsula. Biological Invasions, 11(4): 1017-1031.

Seifert B., D’Eustacchio D., Kaufmann B., Centorame M., LORITE P., Modica M.V., 2017 - Four species within the supercolonial ants of the Tapinoma nigerrimum complex revealed by integrative taxonomy (Hymenoptera: Formicidae). - Myrmecological News, 24: 123-144.

Spotti F.A., Castracani C., Grasso D.A., Fanfani A., Mori A., 2010 - The community structure temporal development of Castelporziano ant fauna. - Redia, XCIII: 89-93.

Suarez A.V., Holway D.A., CASE T.J., 2001 - Patterns of spread in biological invasions dominated by longdistance jump dispersal: Insights from Argentine ants.Proceedings of the National Academy of Sciences, 98(3): 1095-1100.

Suarez A.V., Yeh P., Case T.J., 2005 - Impacts of Argentine ant on avian nesting success. - Insectes Sociaux, 52(4): 378-382.

Suarez A.V., Mcglynn T.P., Tsutsui N.D., $2010-$ Biogeographic and taxonomic patterns of introduced ants. In: Ant ecology, Lach R., Parr C.L., Abbott K.L. Eds., Oxford University Press, pp. 233-244.

Tsutsui N.D., SuArez A.V., 2003 - The colony structure and population biology of invasive ants. - Conservation biology, 17(1): 48-58.

WARD P.S., 1987 - Distribution of the introduced Argentine ant (Iridomyrmex humilis) in natural habitats of the Lower Sacramento Valley and its effects on the indigenous ant fauna. - Hilgardia, 55(2). 